\title{
Genetic Diversity and Geographic Relationship Studies in Chickpea (Cicer arietinum L.) Germplasm
}

\author{
M. Manikanta Sai Chandu*, G. Roopa Lavanya, Y.H. Ranganatha and \\ O. Manikanteswara
}

Department of Genetics and Plant breeding, Naini Agricultural Institutute, Sam Higginbottom University of Agriculture Technology and Sciences, Allahabad, 211007,UttarPradesh, India

*Corresponding author

\begin{abstract}
A B S T R A C T

\begin{tabular}{|c|}
\hline Keywords \\
\hline $\begin{array}{l}\text { Chickpea, } \\
\text { Variability, } \\
\text { Heritability, } \\
\text { Genetic advance, } \\
\text { GCV, PCV, Genetic } \\
\text { divergence }\end{array}$ \\
\hline Article Info \\
\hline $\begin{array}{l}\text { Accepted: } \\
15 \text { July } 2018 \\
\text { Available Online: } \\
10 \text { August } 2018\end{array}$ \\
\hline
\end{tabular}

The present investigation was carried out among the 42 germplasm of chickpea, to study the nature and magnitude of genetic divergence using Mahalanobis's D ${ }^{2}$ Statistics, during rabi season of 2017 at Naini Agricultural Institute, S.H.U.A.T.S., Allahabad, U.P. Based on $\mathrm{D}^{2}$ analysis, the 42 germplasm lines were grouped into seven different clusters indicating diverse nature of material studied. Cluster V was the largest with 12 genotypes followed by cluster VII (10 genotypes) and cluster VI (7 genotypes). Among the seed yield components, seed index followed by number of days to maturity and Biological yield per plant contributed maximum towards the divergence. Cluster I showed the maximum mean value for seed yield. The intra and inter cluster divergence among the genotypes was varying in magnitude. The intra- cluster distance was maximum in cluster III followed by clusters V and VII. The widest inter cluster distance was noted between cluster III and VII followed by IV and VII, II and VII. Genotypes C-108 and C-138 were identified most desirable with high seed yield/plant. Cluster III and VII were most diverse to each other, therefore genotypes present in these clusters are expected to provide a broad spectrum of variability in segregating generations and may be used as parents for future hybridization programme.
\end{abstract}

\section{Introduction}

The genus Cicer comprises 34 wild perennial, eight annual wild and one annual cultivated species. Chickpea (Cicer arietinum) is the third most important food legumes in the world in terms of area (11.55 million hectares) and production (10.46 million tons) (FAOSTAT 2014). India is the largest producer of chickpea in the world sharing about $70 \%$ of area and production (FAOSTAT 2014). In India, chickpea is cultivated in an area of 9.39 million ha with the production of 9.53 million tons (Dixit 2015 ) with productivity of $960 \mathrm{~kg} / \mathrm{ha}$.

In India, productivity is low as compared to other chickpea producing countries like Mexico (1809 kg/ha), Australia (1268 kg/ha), Ethiopia $(1265 \mathrm{~kg} / \mathrm{ha})$ Hence, utilization of 
diverse germplasm is the key to develop high yielding varieties to bridge this yield gap.

In chickpea, there are reports available on the evaluation of genetic stock in agromorphological traits (Singh et al., 1990; Farshadfar and Farshadfar, 2008; Ali et al., 2010; Wadikar et al., 2010). These reports suggest that pod/plant, 100 seed weight $(\mathrm{g})$, plant height and number of primary branches/plant are the major yield contributing traits (Singh et al., 1990). To strengthen ongoing breeding program, study of the available natural genetic variation is of immense importance. It is imperative to collect and evaluate germplasm precisely to draw valid conclusion. Limited or lack of genetic variability is important factor for the limited progress achieved in increasing the productivity of grain legumes including chickpea (Sachin0020et al., 2014). When the parents utilized in a cross are genetically similar, it is quite likely that the different lines derived reveal low diversity. On the contrary, when diverse parents are used in obtaining a segregating population, the derived lines reveal greater diversity (Borate et al., 2010).

In any program aimed at genetic amelioration of yield, genetic diversity is the basic requirement. Effective hybridization program between genetically diverse parents will lead to considerable amount of heterotic response in $F_{1}$ hybrids and broad spectrum of variability in segregating generations.

Mahalanobis's $\mathrm{D}^{2}$ statistics is a powerful tool in quantifying the degree of variability at the genotype level (Mahalanobis, 1936). So, the present experiment was formulated to study the genetic divergence and clustering pattern of the chickpea genotypes for selection of suitable parents for utilizing in hybridization programme and to study the genetic parameters attributing to yield.

\section{Materials and Methods}

The present investigation was carried out at the Field Experimentation Centre, Department of Genetics and Plant Breeding, Naini Agricultural Institute, Sam Higginbottom University of Agriculture, Technology and Sciences, Allahabad, U.P. (India) during Rabi-2017. The experimental materials consist of 42 genotypes obtained from Dept. of GPB, SHUATS. The experiment was laid out in Randomized Complete Block Design with 3 replications. The genotypes were sown by hand dibbling in each plot by imposing randomization in each replication along with check UDAY. The spacing of row to row $30 \mathrm{~cm}$ and plant to plant $10 \mathrm{~cm}$. The fertilizer dose of 20:40:40 NPK $\mathrm{kg} / \mathrm{ha}$ is applied as Nitrogen as two splits, phosphorus and potassium as basal dose. All recommended package of practices was followed during the cropping period to raise a good crop. Observations were recorded in each plot and replication by taking five plants randomly for 9 quantitative characters viz. Mean data for 9 characters viz., days to $50 \%$ flowering, days to maturity, plant height, number of primary branches per plant, number of pod per plant, biological yield, harvest index, seed index and seed yield per plant. The experimental data was analyzed statistically to find out the significance of mean difference between varieties and different genetic parameters were estimated. Analysis of variance was performed to test the significance of difference among the genotypes for the characters studied. Mahalanobis $\mathrm{D}^{2}$ technique (Mahalanobis, 1936) was used to analyze genetic diversity.

\section{Results and Discussion}

Forty two genotypes of Chickpea showed significant differences among all characters under study. Seed index contributed maximum towards divergence followed by 
days to maturity, the same characters are positively associated with yield and are the main yield components in chickpea.

The parameters of genetic variability revealed high PCV and GCV values for seed yield followed by Harvest index, Biological yield per plant and Seed Index respectively, (Table 1) indicating that these traits could be used as selection indices for yield improvement. Similar findings were reported by Sachin et al., (2014) and Borate et al., (2010). High heritability (> $60 \%$ ) was observed in almost all characters studied. The high heritability with high genetic advance was recorded for seed index $(98.10 \%, 36.29 \%)$ followed by Biological yield per plant $(75.7,37.33 \%)$. The estimates of GA ranged from 0.29 and 21.27 with the highest estimate in case of Harvest Index. The highest genetic advance as per cent of mean was observed for Harvest Index $(38.20 \%)$ followed by seed yield/plant (37.38), Biological yield per plant (37.33) and Seed Index (36.29). It indicates that most likely the heritability is due to additive gene effects and selection for these traits may be rewarding. Similar findings have been reported by Sachin et al., (2014), Syed et al., (2012) and Zakia et al., (2012) in chickpea.
The forty two genotypes studied were grouped into seven clusters (Table 2 and Fig. 1) by using Mahalanobis $D^{2}$ statistic, Cluster $\mathrm{V}$ was the largest with 12 genotypes followed by cluster VII (10 genotypes), cluster VI (7 genotypes), cluster I (5 genotypes), clusters III and IV (3 genotypes) and cluster II (2 genotypes).

The average interand intra cluster $\mathrm{D}^{2}$ values among seven clusters were computed and have been given in the table 3. The average intra cluster distance ranged from 21.03 to 68.85. The maximum intra cluster distance was recorded for cluster III (68.85) followed by cluster $\mathrm{V}$ (39.87) while the minimum intra cluster distance was recorded for cluster II (21.03).

The inter cluster $\mathrm{D}^{2}$ value was maximum between cluster III and VII (669.29) followed by cluster IV and VII (436.56), cluster II and VII (405.46), I and VII (371.68) suggesting that the genotype present in these clusters may be used as parents for hybridization programme to develop desirable type as heterosis can be best exploited and chance of getting transgressive segregants are maximum when generating diverse lines are crossed.

Table.1 Estimates of genetic parameters for nine quantitative characters in chickpea

\begin{tabular}{|c|c|c|c|c|c|c|}
\hline \multirow{2}{*}{ S. No. } & Characters & \multicolumn{2}{|c|}{ Coefficient of variation } & $\begin{array}{c}\text { Heritability } \\
(\%)(b s)\end{array}$ & $\begin{array}{c}\text { Genetic } \\
\text { Advance }\end{array}$ & $\begin{array}{c}\text { Gen. } \\
\text { Advance as } \\
\text { \% of mean }\end{array}$ \\
\cline { 3 - 6 } & & Genoypic & Phenotypic & & & \\
\hline $\mathbf{1}$ & Days to 50\% flowering & 4.31 & 4.81 & 80.10 & 6.07 & 7.95 \\
\hline $\mathbf{2}$ & Plant height & 16.57 & 18.92 & 76.70 & 14.63 & 29.89 \\
\hline $\mathbf{3}$ & Branches/Plant & 8.68 & 14.05 & 38.10 & 0.29 & 11.04 \\
\hline $\mathbf{4}$ & Number of pods/plant & 13.49 & 18.63 & 52.50 & 6.42 & 20.14 \\
\hline $\mathbf{5}$ & Days of maturity & 5.20 & 5.62 & 85.50 & 11.51 & 9.90 \\
\hline $\mathbf{6}$ & Biological yield/plant & 20.82 & 23.93 & 75.70 & 8.80 & 37.33 \\
\hline $\mathbf{7}$ & Harvest index & 21.69 & 25.38 & 73.10 & 21.27 & 38.20 \\
\hline $\mathbf{8}$ & Seed index & 17.78 & 17.95 & 98.10 & 7.40 & 36.29 \\
\hline $\mathbf{9}$ & Seed yield/ plant & 21.62 & 25.77 & 70.40 & 4.77 & 37.38 \\
\hline
\end{tabular}


Table.2 Distribution of the 42 genotypes of chickpea into different clusters

\begin{tabular}{|l|l|l|}
\hline \multicolumn{1}{|c|}{ Cluster No. } & No. of genotypes & \multicolumn{1}{|c|}{ Genotypes included } \\
\hline I & 5 & C-201, C-1021, C-224, C-223, C-108 \\
\hline II & 2 & C-1026, C-112 \\
\hline III & 3 & C-1023, C-115, C-226 \\
\hline IV & 3 & C-207, C-133, C-1027 \\
\hline V & 12 & $\begin{array}{l}\text { C-128, C-131, C-1014, UDAY, C-138, C-137, C-136, C-1015, C- } \\
222, C-1028, C-1025, C-1022\end{array}$ \\
\hline VI & 7 & C-1012, C-130, C-132, C-1013, C-127, C-129, C-213 \\
\hline VII & 10 & $\begin{array}{l}\text { C-135, C-205, C-216, C-206, C-203, C-1011, C-126, C-210, C-114, } \\
\text { C-1044 }\end{array}$ \\
\hline
\end{tabular}

Table.3 Intra (diagonal) and inter cluster average distances $\left(D^{2}\right)$ for different quantitative characters in 42 genotypes of chickpea

\begin{tabular}{|r|c|c|c|c|c|c|c|}
\hline $\begin{array}{c}\text { Cluster } \\
\text { number }\end{array}$ & I & II & III & IV & V & VI & VII \\
\hline I & 34.23 & 63.75 & 86.35 & 75.99 & 116.47 & 114.08 & 371.68 \\
\hline II & & 21.03 & 113.18 & 199.01 & 108.51 & 198.99 & 405.46 \\
\hline III & & & 68.85 & 128.77 & 281.62 & 283.18 & 669.29 \\
\hline IV & & & & 25.41 & 213.18 & 112.51 & 436.56 \\
\hline V & & & & & 39.87 & 86.01 & 146.72 \\
\hline VI & & & & & & 32.01 & 150.17 \\
\hline VII & & & & & & & 37.03 \\
\hline
\end{tabular}


Table.4 Cluster mean values of seven clusters for nine characters of chickpea

\begin{tabular}{|c|l|c|c|c|c|c|c|c|}
\hline $\begin{array}{c}\text { Sl. } \\
\text { No }\end{array}$ & \multicolumn{1}{|c|}{ Cluster No. } & & & & & & \\
\hline $\mathbf{1}$ & $\begin{array}{l}\text { Character } \\
\text { Days to 50\% } \\
\text { flowering }\end{array}$ & 78.00 & 82.33 & 79.55 & 71.77 & 78.16 & 72.85 & 75.43 \\
\hline $\mathbf{2}$ & Plant height & 52.93 & 56.40 & 52.57 & 41.40 & 49.88 & 48.55 & 45.86 \\
\hline $\mathbf{3}$ & No. of Branches/Plant & 2.65 & 2.43 & 2.73 & 2.75 & 2.75 & 2.63 & 2.77 \\
\hline $\mathbf{4}$ & No. of pods/plant & 32.49 & 30.50 & 29.20 & 28.80 & 33.14 & 30.74 & 32.87 \\
\hline $\mathbf{5}$ & Days to maturity & 117.80 & 128.00 & 118.55 & 107.55 & 120.30 & 110.28 & 114.26 \\
\hline $\mathbf{6}$ & Biological yield/plant & 22.40 & 27.63 & 21.64 & 19.21 & 27.98 & 20.28 & 22.30 \\
\hline $\mathbf{7}$ & Harvest Index & 69.00 & 53.39 & 61.45 & 66.76 & 50.17 & 60.39 & 47.74 \\
\hline $\mathbf{8}$ & Seed Index & 23.90 & 23.83 & 27.22 & 24.47 & 19.98 & 20.14 & 15.39 \\
\hline $\mathbf{9}$ & Seed yield per plant & 15.78 & 14.61 & 13.86 & 12.90 & 13.49 & 11.76 & 10.42 \\
\hline
\end{tabular}

Fig.1 Cluster diagram depicting intra and inter cluster distances

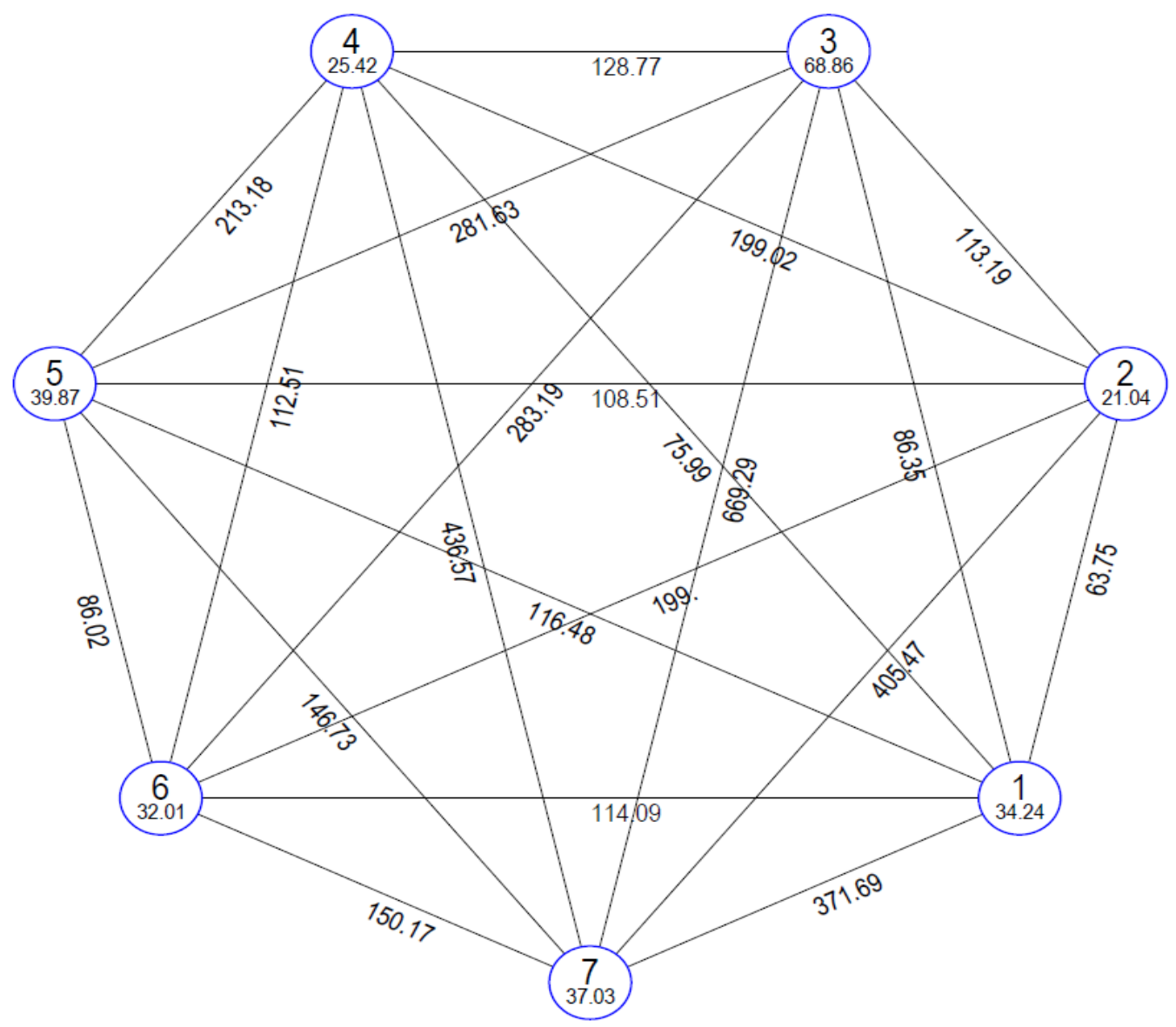

Euclidean ${ }^{2}$ Distance (Not to the Scale) 
Cluster means were found highest for different characters (Table 4) viz., Cluster V showed highest mean performance for seed yield (227.38). Cluster I showed highest mean performance for Harvest Index (69.00) and Seed yield per plant (15.78). Cluster II showed higher mean performance for plant height (56.40), Days to flowering (82.33) and Days to maturity (128.00). Cluster III for Seed Index (27.22). Cluster V showed highest mean performance for Number of pods/plant (33.14) and biological yield per plant (27.98). Cluster VII for No. of branches/plant (2.77). Based upon $\mathrm{D}^{2}$ values, per cent contribution of different characters towards divergence was obtained. Among the nine characters studied the most important characters contributing to the divergence were seed index $(69.22 \%)$ followed by number of days to maturity (8.94\%) and Biological yield per plant $(8.01 \%)$, plant height $(5.23 \%)$, days to $50 \%$ flowering $(3.60 \%)$ and harvest index $(2.44 \%)$. These results are in agreement to the earlier findings by Rajkumar et al., 2015, Sachinet al., 2014, Syed et al., 2012 and Zakiaet al., 2012.

Genotypes belonging to clusters separated by high genetic distance may be used in hybridization program to obtain a wide spectrum of variation among the segregates in the present study and similar suggestion had been made by Sachin et al., (2014), Syed et al., (2012) and Zakia et al., (2012). The genotypes included in the diverse clusters namely II, III, IV and VII hold good promise as parents for obtaining potential hybrids and thereby creating greater variability of these characters to improve the yield.

The results from the present investigation conclude that chickpea genotypes C-108 and C-138 are identified as desirable genotypes with highest number of pods per plant and seed yield per plant. High estimates of GCV and PCV were recorded for seed yield per plant, harvest index, biological yield and plant height. High heritability coupled with high genetic advance as percent of mean observed for the characters seed index and biological yield hence these parameters could be used for selection. Clusters III and VII were most diverse to each other, therefore genotypes present in these clusters are expected to provide a broad spectrum of variability in segregating generations and may be used as parents for future hybridization programme to develop desirable genotype.

\section{References}

Ali, Q. Ahsan, M. and Farooq, J. 2010. Genetic variability and trait association in chickpea (Cicer arietinum L.) genotypes at seedling stage. Elect. J. Plant Breed., 1:334-341.

Borate, V.V. Dalvi, V.V. and Jadhav, B.B. 2010. Estimates of genetic variability and heritability in chickpea. $J$. Maharashtra Agric. Univ., 35(1): 47-49.

Dixit, G.P. 2015 Project Coordinator Report, 2014-15. All India Coordinated Research Project on Chickpea, IIPR, Kanpur: 28-29.

Farshadfar, M. and Farshadfar, E. 2008. Genetic variability and path analysis of chickpea (Cicer arietinum) landraces and lines. J. Appl. Sci., 8: 3951-3956.

Food and Agricultural Organization of the United Nations. 2013. FAO Statistical Databases. Available at http://faostat. fao.orgl FAO, Rome.

Mahalanobis, P.C. 1936. Study on the generalized distance in statistics. Proc. Nat. Ins. Sci. India. 2: 49-55.

Rajkumar, Kuldeep, Suneeta, P., Anita, B. and Vijay, P. 2015. Genetic diversity analysis in chickpea grown under heat stress conditions of Madhya Pradesh. Elect. J. Pl. Breed., 6(4): 962-971.

Sachin, D., Parhe, P.N., Harer and Nagawade, D.R. 2014. Investigation of genetic 
divergence in Chickpea (Cicer arietinum L.) genotypes. The Bioscan, 9(2):879-882.

Singh, K.B. Bejiga, G. and Malhotra, R.S. 1990. Association of some characters with seed yield in chickpea collections. Euphytica, 9: 83-88.

Syed, M.A., Islam, M.R., Hossain, M.S., Alam, M.M. and Amin, M.N. 2012. Genetic divergence in Chickpea (Cicer arietinum L.). Bangladesh J. Agril.
Res., 37(1): 129-136.

Wadikar, P.B. Ghodke and Pole, S.P. 2010. Genetic divergence for productivity traits in chickpea. Journal of Food legumes, 23: 245-246.

Zakia, A., Abdul, S.M., Mohammad, N. and Nasrullah, K. 2012. Diversity analysis of chickpea (Cicer arietinum L.) germplasm and its implications for conservation and crop breeding. J. Agri. Sci., 3(5): 723-731.

\section{How to cite this article:}

Manikanta Sai Chandu, M., G. Roopa Lavanya, Y.H. Ranganatha and Manikanteswara, O. 2018. Genetic Diversity and Geographic Relationship Studies in Chickpea (Cicer arietinum L.) Germplasm. Int.J.Curr.Microbiol.App.Sci. 7(08): 2734-2740.

doi: https://doi.org/10.20546/ijcmas.2018.708.286 